\title{
Modeling intrinsic bioremediation for interpret observable biogeochemical footprints of BTEX biodegradation: the need for fermentation and abiotic chemical processes
}

\author{
Max Maurer ${ }^{1 *} \&$ Bruce E. Rittmann ${ }^{2}$ \\ ${ }^{1}$ Engineering Science Department, EAWAG, Überlandstrasse 133, CH-8600 Dübendorf, Switzerland, (*author \\ for correspondence: e-mail: max.maurer@eawag.ch); ${ }^{2}$ Environmental Engineering and Science, Northwestern \\ University, 2145 Sheridan Road, Evanston, IL 60208-3109, USA (e-mail: b-rittmann@northwestern.edu)
}

Accepted 15 August 2003

Key words: calcite, dissolution, fermentation, footprints, intrinsic bioremediation, iron reduction, methanogenesis, natural attenuation, precipitation, sulfate reduction, sulfide

\begin{abstract}
The intrinsic bioremediation of BTEX must be documented by the stoichiometric consumption and production of several other compounds, called 'footprints' of the biodegradation reaction. Although footprints of BTEX biodegradation are easy to identify from reaction stoichiometry, they can be confounded by the stepwise nature of the biodegradation reactions and by several abiotic chemical reactions that also produce or consume the footprints. In order to track the footprints for BTEX biodegradation, the following reactions need to be considered explicitly: (1) fermentation and methanogenesis as separate processes, (2) precipitation and dissolution of calcite, (3) precipitation and dissolution of amorphous iron monosulfide (FeS), (4) conversion of FeS into the thermodynamically stable pyrite $\left(\mathrm{FeS}_{2}\right)$ with loss of sulfide and abiotic formation of $\mathrm{H}_{2}$, and (5) reductive dissolution of solid iron(III) by oxidation of sulfide. We critically review the research that underlies why these mechanisms must be included and how to describe them quantitatively. A companion manuscript develops and applies a mathematical model that includes these reactions.
\end{abstract}

\section{Introduction}

\section{Footprints of BTEX biodegradation}

Setting up a monitoring program and interpreting its results are the keys for assessing in-situ bioremediation (NRC 1993, 2000). The biological conversion of a pollutant must be documented by the stoichiometric consumption and production of several other compounds, called 'footprints' of the biodegradation reaction (NRC 2000). This knowledge, properly quantified in a mathematical model, creates a 'body of evidence' documenting the efficiency of bioremediation. When natural attenuation is being evaluated, footprints take on pre-eminent importance, because the 'technology' of natural attenuation is demonstrating the cause-andeffect relationship between the decrease in pollutant concentration and the biodegradation reaction (NRC 2000; Rittmann 2004).

To be able to track footprints correctly, the chemical fate, as well as the biological fate, of the footprints has to be known. For example, precipitation and dissolution of solids, like iron sulfide or calcium carbonate, can confound interpretation of them as footprints of biodegradation. Furthermore, the biological model must provide an accurate representation of the types of microbially catalysed reactions. The NRC (2000) did not provide explicit guidance for how to handle these potentially confounding factors. Currently available computer codes (e.g., BIOPLUME III, Radai et al. 1998; RT3D, Clement 1997; UTCHEM, Pope et al. 1999; TBC, Schäfer et al. 1998a, b) concentrate mainly on groundwater transport and have relatively simplified models of the biological reactions and no chemical processes. 
We present a critical review of the important biological and chemical processes for the in-situ biodegradation of BTEX. We chose BTEX because they are very frequent groundwater pollutants and candidates for natural attenuation (NRC 2000). Not included in this review are all microbial mediated (re-)oxidation of reduced components like methane or iron(II). The focus of this review is on the formation and dissolution of iron sulfides, iron oxides, and calcium carbonate, as well as on distinguishing between fermentation and methanogenesis. A companion paper (Maurer \& Rittmann 2004) incorporates these mechanisms into a biogeochemical model for BTEX bioremediation.

\section{Microbial processes}

Numerous laboratory and field studies have shown that microorganisms in the subsurface can degrade BTEX under aerobic and anaerobic conditions. Microorganisms can utilize the alternate electron acceptors oxygen, nitrate, iron(III), manganese(IV), and sulfate for the degradation of BTEX compounds. Furthermore, fermentation coupled to methanogenesis is possible. Good reviews on the use of the different electron acceptors by microorganisms under laboratory and field conditions are given in Morgan et al. (1993), Wiedermeier et al. (1995), Hollinger \& Zehnder (1996), Salanitro et al. (1997), and NRC (2000). Here, we focus on the reactions involving fermentation and methanogenesis, because the two-step process is a novel feature of bioremediation modelling and needs to be added. We also provide necessary background on the other acceptors and their footprints. In order to keep the example reactions illustrative, we neglect the formation of biomass in this manuscript. Microbial growth has a significant influence on the footprints, and the kinetics for and stoichiometric coefficients for biomass are presented in the companion manuscript (Maurer and Rittmann, this volume).

\section{BTEX biodegradation with different electron acceptors}

\section{Oxygen}

Bielefeldt \& Stensel (1999a, b) determined in mixed cultures experiments the kinetics of aerobic BTEX degradation. Generally, they found similar degradation rates for benzene, toluene, and ethylbenzene, whereas $o$-xylene was degraded more slowly. These findings agree with many other similar investigations and confirm the relatively easy and rapid degradation of BTEX under aerobic conditions, as long as dissolved oxygen is present. Because aerobic biodegradation begins with oxygenation reactions, which have $\mathrm{O}_{2}$ as a direct reactant (Rittmann et al. 1994; NRC 2000), aerobic biodegradation is limited due to the fact that the dissolved oxygen concentration is typically less than $10 \mathrm{mg} / \mathrm{L}$ (Malmstead et al. 1995).

The footprints of aerobic biodegradation of BTEX are illustrated with the following stoichiometry for toluene $\left(\mathrm{C}_{7} \mathrm{H}_{8}\right)$ :

$$
\mathrm{C}_{7} \mathrm{H}_{8}+9 \mathrm{O}_{2}+3 \mathrm{H}_{2} \mathrm{O} \rightarrow 7 \mathrm{H}_{2} \mathrm{CO}_{3}
$$

The footprints are (per mole of toluene) consumption of 9 moles of $\mathrm{O}_{2}$, generation of 7 moles of inorganic carbon $\left(\mathrm{H}_{2} \mathrm{CO}_{3}\right)$, and no change of alkalinity. Alkalinity consumption would be shown by production of acidic hydrogen, or $\mathrm{H}^{+}$.

\section{Nitrate}

Reinhard et al. (1997) investigated the in-situ biotransformation of BTEX in a gasoline-contaminated aquifer. Under nitrate-reducing conditions, toluene, ethylbenzene, and $m$-xylene were transformed without a lag phase in less than 10 days, and $o$-xylene was transformed in 72 days. Benzene was not removed. These findings are typical for many of the published investigations, where benzene seems not to be utilized when nitrate is the electron acceptor. However, Major et al. (1988) and Gersberg et al. (1991) reported in their laboratory experiments biodegradation of benzene. Apparently, some denitrifying microorganisms can oxidize benzene, although it is not clear what circumstances allow it.

The footprints for nitrate reduction are illustrated for toluene:

$$
\begin{aligned}
\mathrm{C}_{7} \mathrm{H}_{8}+7.2 \mathrm{NO}_{3}^{-}+7.2 \mathrm{H}^{+} \rightarrow & 7 \mathrm{H}_{2} \mathrm{CO}_{3}+3.6 \mathrm{~N}_{2} \\
& +0.6 \mathrm{H}_{2} \mathrm{O}
\end{aligned}
$$

The footprints (per mole of toluene) are consumption of 7.2 moles of nitrate, generation of 7 moles of inorganic carbon, and generation of 7.2 equivalents of alkalinity (loss of $\mathrm{H}^{+}$).

\section{$\operatorname{Iron}(I I I)$}

Kostka \& Nealson (1995) showed that microorganisms are capable of bringing about rapid reduction and dissolution of solid iron(III). Increased iron(II) concentrations in different groundwater sites (overview in Rafai et al. 1998) indicate that iron(III) is used as an electron acceptor. Coates et al. (1999) isolated 
from contaminated aquifer material a Fe(III)-reducing strain that had been adapted for rapid oxidation of toluene coupled to Fe(III) reduction. Meckenstock et al. (1999) proved that the iron-reducing strain Geobacter metallireducens oxidized toluene.

The footprints for toluene oxidation coupled to $\mathrm{Fe}(\mathrm{OH})_{3(\mathrm{~s})}$ reduction are illustrated by:

$$
\begin{aligned}
\mathrm{C}_{7} \mathrm{H}_{8}+36 \mathrm{Fe}(\mathrm{OH})_{3(\mathrm{~s})}+72 \mathrm{H}^{+} \rightarrow & 7 \mathrm{H}_{2} \mathrm{CO}_{3}+36 \mathrm{Fe}^{2+} \\
& +87 \mathrm{H}_{2} \mathrm{O}
\end{aligned}
$$

The footprints (per mole of toluene) are production of 36 moles of $\mathrm{Fe}^{2+}$, production of 72 equivalents of alkalinity, and generation of 7 moles of inorganic carbon.

\section{Sulfate}

In slug tests in a gasoline-contaminated aquifer, Reinhard et al. (1997) found that, under sulfate-reducing conditions, toluene, $m$-xylene, and $o$-xylene were completely transformed in less than 50 days, while ethylbenzene was removed in 60 days. Lovley et al. (1995) showed in their incubation of sediments that benzene was oxidized under sulfate-reducing conditions. The presence of nitrate inhibited or at least out-competed sulfate reduction (Hutchins et al. 1998).

The oxidation of toluene coupled to sulfate reduction shows these typical footprints:

$$
\begin{aligned}
\mathrm{C}_{7} \mathrm{H}_{8}+4.5 \mathrm{SO}_{4}^{2-}+9 \mathrm{H}^{+}+3 \mathrm{H}_{2} \mathrm{O} \rightarrow & 7 \mathrm{H}_{2} \mathrm{CO}_{3} \\
& +4.5 \mathrm{H}_{2} \mathrm{~S}
\end{aligned}
$$

The footprints of sulfate reduction (per mole of toluene) are loss of 4.5 moles of sulfate, production of 4.5 moles of hydrogen sulfide, production of 9 equivalents of alkalinity, and generation of 7 moles of inorganic carbon.

\section{Significance of distinguishing fermentation from methanogenesis}

The evidence is strong that all BTEX compounds can be metabolized under methanogenic conditions, and the conversion of BTEX to methane is a twostep process. In the first step, BTEX is fermented to aliphatic organic acids - ultimately acetic acid hydrogen, and $\mathrm{CO}_{2}$. In the second step, methanogens convert the acetic acid and hydrogen to methane. The fermenters and methanogens are genetically and physiologically distinct microorganisms, and both must be present in order that the electron equivalents in BTEX are fully stabilized to methane. The fermentation process depends very strongly on the hydrogen concentration in the environment. Low concentration favours the production of acetate and hydrogen, while higher $\mathrm{H}_{2}$ concentration yields in less hydrogen and more long-chain fatty acids like propionate. The underlying thermodynamic-determined relationships are discussed in great detail in the literature of anaerobic microbiology (e.g., Dolfing 1988).

Field investigations confirm that, after the depletion of electron acceptors, aliphatic organic acids accumulate due to fermentation of complex organic molecules (Cozzarelli et al. 1994; Chaudhuri \& Wiesmann 1996; Landmeyer et al. 1996). Revesz et al. (1995) concluded from the stable isotopic ratios of C and $\mathrm{H}$ in the groundwater of a crude-oil spill that the methane found came mostly from acetate. Hydrogen, the other important product of fermentation, was detected at contaminated sites by Lovley et al. (1994), Vroblesky \& Chapelle (1994), Chapelle et al. (1995, 1996), Postma \& Jakobsen (1996), Jakobsen et al. (1998).

Acton \& Barker (1992) reported from their in situ biodegradation columns that, in all cases, aromatic hydrocarbon attenuation was attributed to biodegradation by the combined activity of methanogens and fermenting bacteria. Similar findings are reported by Edwards \& Grbic-Galic (1994). In their strictly anaerobic experiments, toluene and $o$-xylene were completely mineralized by aquifer-derived microorganisms. The adaptation periods before the onset of degradation were long (100 to 120 days for toluene degradation and 200 to 255 days for $o$-xylene). In the anaerobic column experiments of Hunkeler et al. (1998), significant amounts of toluene, $p$-xylene, and naphthalene were converted to methane. Despite the findings of Patel et al. (1991) that BTEX significantly inhibited methane production, Mormile \& Suflita (1996) concluded from their results that the concentrations typically found in groundwater systems do not inhibit methanogenesis.

Grbic-Galic \& Vogel (1987; Vogel \& Grbic-Galic 1986; Grbic-Galic 1991) thoroughly investigated the microbial degradation of benzene and toluene under methanogenic conditions. Important fermentation intermediates before acetate were phenol, cresol, benzoic acid, and aliphatic acids, mainly propionate. Chaudhuri \& Wiesmann (1996) reported kinetic constants for the degradation of toluene with an enriched mixed methanogenic culture in chemostat experiments. They determined the following stoichiometric and kinetic constants for the mixed culture: growth yield: $0.18 \mathrm{~mol}_{\mathrm{C}} \mathrm{mol}_{\mathrm{C}}^{-1}\left(0.35 \mathrm{~g}_{\mathrm{TS}} \mathrm{g}_{\text {Toluene }}^{-1}\right)$, maximum 
specific growth rate: $\mu_{\max }=1.44 \mathrm{~d}^{-1}$; (Monod-)half saturation concentration, $K_{S}=4.7 \mathrm{~g}_{\text {toluene }} \mathrm{m}^{-3}$, and a first-order decay constant of the biomass, $0.084 \mathrm{~d}^{-1}$.

Each step has its own footprints. The following stoichiometry for the fermentation of toluene shows a representative set of footprints for the first step.

$$
\mathrm{C}_{7} \mathrm{H}_{8}+13 \mathrm{H}_{2} \mathrm{O} \rightarrow 2 \mathrm{CH}_{3} \mathrm{COOH}+10 \mathrm{H}_{2} \mathrm{CO}_{3}
$$

The footprints of the fermentation step are (per mole of toluene) production of 2 moles of acetic acid $\left(\mathrm{CH}_{3} \mathrm{COOH}\right), 10$ moles of $\mathrm{H}_{2}$, and 3 mole of inorganic carbon. Methanogenesis of the acetic acid yields

$$
2 \mathrm{CH}_{3} \mathrm{COOH}+2 \mathrm{H}_{2} \mathrm{O} \rightarrow 2 \mathrm{CH}_{4}+2 \mathrm{H}_{2} \mathrm{CO}_{3}
$$

which has footprints (per mole of original toluene) of production of 2 moles each of methane $\left(\mathrm{CH}_{4}\right)$ and inorganic carbon. Methanogenesis of the hydrogen produced from fermentation of toluene yields

$$
10 \mathrm{H}_{2}+2.5 \mathrm{H}_{2} \mathrm{CO}_{3} \rightarrow 2.5 \mathrm{CH}_{4}+7.5 \mathrm{H}_{2} \mathrm{O}
$$

which has footprints (per mole of original toluene) of production of 2.5 moles of $\mathrm{CH}_{4}$ and consumption of 2.5 moles of inorganic carbon. Inorganic carbon is consumed as the electron acceptor for methanogenesis by hydrogen oxidation, but it is a product of methanogenesis from acetate and fermentation. Likewise, $\mathrm{H}_{2}$ is produced from fermentation, but consumed by methanogenesis coupled to $\mathrm{H}_{2}$ oxidation. Therefore, in order to be able to track the footprints of BTEX biodegradation under methanogenic conditions, footprints of fermentation and the conversions of hydrogen and acetate into methane need to be considered separately and explicitly.

The accumulation of methanogens and, hence, the generation of methane can lag well behind the accumulation of fermenters and the generation of acetate and $\mathrm{H}_{2}$. The main reason is that the growth of methanogens cannot occur until fermentation has produced significant acetate and hydrogen for a sustained period. Therefore, it is possible to have major biodegradation of BTEX without seeing the methane footprint.

\section{Chemical processes}

Many of the footprints of BTEX degradation can be confounded by chemical reactions. Sulfide, for example, precipitates with iron(II). Thus, precipitation of $\mathrm{FeS}$ removes the footprints of microbial sulfate and iron(III) reduction. Other abiotic reactions that confound microbial footprints involve precipitation or dissolution of solids, including $\mathrm{CaCO}_{3}$ and $\mathrm{Fe}(\mathrm{OH})_{3}$. The degree to which the precipitation and dissolution reactions occur depends on the ion-solubility product of the dissolved ions and the kinetics of the precipitation or dissolution reaction. The chemical composition of the solids, the different possible reactions, and the underlying kinetics are non-trivial aspects that must be resolved if the abiotic factors are to be incorporated properly into a biogeochemical model of BTEX bioremediation.

In this section, we address the following abiotic reactions that can confound biotic footprints:

- Dissolution and precipitation of calcium carbonate, which affect the inorganic carbon concentration, the alkalinity, and the $\mathrm{pH}$ of the groundwater.

- Precipitation and dissolution of iron sulfides, which are sinks for iron(II) and sulfide, two important footprints. In one case, $\mathrm{H}_{2}$, another biological footprint, is produced abiotically.

- Reductive dissolution of solid iron(III) coupled to the oxidation of sulfide, which eliminates sulfide from the solution, but adds iron(II).

We neglect the influence of nucleation on the net rate of precipitation, because the subsurface environment provides plenty of nucleation sites, including already present precipitates (e.g., calcite) and bacteria. In addition, we do not discuss any fast equilibrium processes that might play a role in BTEX degradation. These are assembled in the companion paper (Maurer and Rittmann, this volume).

\section{Calcium carbonate $\left(\mathrm{CaCO}_{3}\right)$}

The dissolution of calcite $\left(\mathrm{CaCO}_{3(\mathrm{~s})}\right)$ represents a major part of the chemical erosion of continents. In many environmental and technological systems, the formation or dissolution of calcite has a significant influence on the $\mathrm{pH}$ and the alkalinity, the latter being an important measurable footprint. In natural aqueous environments, calcite is the main calcium carbonate formed chemically. The solubility product of calcite is $10^{-8.48}$ at $25 \mathrm{C}$ (Stumm \& Morgan 1996), with a heat of formation of $-3.07 \mathrm{~kJ} \mathrm{~mol}^{-1}$ (based on a careful review of Plummer \& Busenberg 1982).

\section{Evaluation of the kinetics}

Most publications concerning the calcium carbonate system determine the dissolution or precipitation rate at high over- or under-saturation (e.g., Parsiegla \& 
Katz 1999; Dawe \& Zhang 1997; Spanos \& Koutsoukos 1998; Busenberg \& Plummer 1986; Nilsson \& Sternbeck 1999; Eisenlohr et al. 1999; Nancollas \& Reddy 1971). For these cases, the mechanistic PWPmodel, presented by Plummer, Wigley and Parkhurst (1978), describes the dissolution and precipitation rates well. The PWP model also was verified on aragonite (a different crystalline form of $\mathrm{CaCO}_{3}$ ) by Chou et al. (1989), who suggest a slightly modified and more practical rate equation.

Only a few publications report on precipitation rates systematically determined close to equilibrium and near neutral $\mathrm{pH}$ (see also Plummer et al. 2000). However, groundwater bodies from or in a carbonaterich matrix are usually close to chemical equilibrium and are not far from neutral $\mathrm{pH}$ (Neal et al. 2002; Bariteau \& Thiry 2001; Plummer et al. 2000). For this condition, most of the determined kinetics in the literature are not necessarily applicable. Busenberg \& Plummer (1986) report about the popular PWP-model that, close to equilibrium, the experimental data do not match the PWP model, but they do match a special case of a Freundlich isotherm (Ohara \& Reid 1973):

$$
\begin{gathered}
\rho=k_{\mathrm{diss}} \cdot\left(1-\frac{S_{\mathrm{Ca}} \cdot S_{\mathrm{CO}_{3}}}{K_{\mathrm{eq}}}\right)^{n} \\
\rho=k_{\mathrm{diss}} \cdot(1-\Omega)^{n}
\end{gathered}
$$

where $\rho$ is the net reaction rate $\left(\right.$ mole $\mathrm{m}^{-2} \mathrm{~d}^{-1}$ ), $k_{\text {diss }}$ the rate constant $\left(\right.$ mole $\left.\mathrm{m}^{-2} \mathrm{~d}^{-1}\right), \mathrm{S}_{\mathrm{CO}_{3}}$ are the activities of $\mathrm{Ca}^{2+}$, and $\mathrm{CO}_{3}^{2-}$ respectively $(\mathrm{M}), K_{\text {eq }}$ the solubility constant of calcite $\left(\mathrm{M}^{2}\right), n$ a constant $(-)$, $\Omega$ is called the saturation state, and $(1-\Omega)$ is the thermodynamic difference from equilibrium (Rittmann et al. 2002).

Busenberg \& Plummer (1986) estimated from their experiments that the parameter $n$ is 0.90 for calcite and 1.16 for aragonite. These values indicate that, close to equilibrium, precipitation and dissolution of calcite do not deviate much from the theoretically derivable form having $n=1$ (i.e., assuming that the forward and backward reaction rates are equal at equilibrium). Similar conclusions were found by Wollast (1990) and Katsifaras and Spanos (1999). The empirical model with $n=1$ also is consistent with the observation that, at neutral $\mathrm{pH}(\mathrm{pH}>6)$ and for low deviations from equilibrium, precipitation and dissolution of calcite are dominated by surface reaction kinetics and are not inhibited by diffusion effects (Gutjahr et al. 1996; Plummer et al. 1978).
Table 1. Kinetic parameters (see Equations (1) and (2)) for calcite dissolution (at $20{ }^{\circ} \mathrm{C}$ ) according to the results of Svensson \& Dreybrodt (1992). $n_{1}$ is the exponent far from the equilibrium $(\Omega<x$, whereas $n_{2}$ is valid for conditions close to the equilibrium $(\Omega>x)$

\begin{tabular}{lrr}
\hline Parameter & \multicolumn{1}{l}{ Limestone } & \multicolumn{1}{l}{ Marble } \\
\hline$\rho\left(\mathrm{mmol} \mathrm{cm}^{-2} \mathrm{~s}^{-1}\right)$ & $1.8 \times 10^{-7} \pm 0.06$ & $1.8 \times 10^{-7} \pm 0.21$ \\
$n_{1}(-)$ & $1.9 \pm 0.26$ & $1.9 \pm 0.29$ \\
$n_{2}(-)$ & $3.3 \pm 0.72$ & $3.2 \pm 0.54$ \\
$x(-)$ & $0.78 \pm 0.07$ & $0.70 \pm 0.05$ \\
\hline
\end{tabular}

Svensson and Dreybrodt (1992) also showed in their dissolution experiments that this 'first-order approach' on the difference from equilibrium applies for conditions close to the equilibrium with pure calcite. However, small amounts of impurities in the calcite decreased the dissolution rate and changed the apparent reaction order, especially close to equilibrium. For tested limestone and marble specimens, they found an average rate constant $k_{\text {diss }}$ of $1.8 \times$ $10^{-7} \mathrm{mmol} \mathrm{cm}^{-2} \mathrm{~s}^{-1}$. The exponent $n$ switched from 1.9 for conditions far away from the equilibrium to 3.3 as the saturation state got closer to 1 (see Table 1). Morse \& Berner (1979) and Palmer (1991) also reported this change of the observed reaction order. This change of the reaction rate behaviour is not covered by the PWP model either. In order to expand the application of the PWP model Svensson \& Dreybrodt (1992) suggested a correction factor for the PWP rate expression. This factor is proportional to the amount of surface sites still active for dissolution and depends on the type and concentration of surface-complexing agents.

More mechanistic approaches are surface-speciation models that have rate expressions derived from the several chemical reactions assumed to occur at the calcite interface. The literature contains several studies on the interfacial chemistry of carbonate minerals, and a good review is given in Morse \& Mackenzie (1990). Pokrovsk \& Schott $(2001,2002)$ suggest a model for dolomite $\left(\mathrm{CaMg}\left(\mathrm{CO}_{3}\right)_{2}\right)$ and generalized the approach for divalent metal carbonate. The latest specific kinetic model for the formation and dissolution of calcium carbonate is described in Nilsson \& Sternbeck (1999). Based on experimental results and the work of VanCappellen et al. (1993) and Sternbeck (1997), they proposed a set of rate-determining reactions with the corresponding parameters. 
In conclusion, surface-speciation models hold promise for explaining observed behaviours of calcite for all saturation states and different interfering molecules, but more research is needed to confirm the surface speciation and the corresponding rates. For dissolution and precipitation far away from equilibrium $(\Omega<0.6$ or $\Omega>1.5)$, the PWP rate equation gives good results. Around the thermodynamic equilibrium of calcite $(1.5>\Omega>0.6)$, growth rate is extremely sensitive to the saturation state. Currently, the empirical rate equation (Equation (1)) is the only easy applicable model that quantifies the calcite dissolution and formation rate sufficiently.

\section{Inhibition}

Complexing agents of calcium or carbonate have an influence on the calcite formation and dissolution rate, and the strength of the influence is correlated with the strength of the complex (Morse \& Mackenzie 1990). The influence of ortho-phosphate on the dissolution or precipitation rate of calcite was investigated in several publications (e.g., Morse \& Berner 1979; Katsifaras \& Spanos 1999; Svensson \& Dreybrodt 1992; Millero et al. 2001). Generally, the effect of phosphate is attributed to the blocking of active growth sites and the inhibition of the dissolution of vaterite (an intermediate of calcite precipitation/dissolution). Magnesium does not act as a real inhibitor, but changes the form of precipitate. $\mathrm{Mg}^{2+}$ is included into the crystal lattice, and the new product has, compared with pure calcite, different solubility and precipitation kinetics (Morse \& Mackenzie 1990). A recent revaluation of the thermodynamic properties of dolomite (calcium magnesium carbonate) can be found in Sherman \& Barak (2000).

Analogously, the inclusion of calcium sulfate in calcite seems to change the crystal lattice strongly. The presence of $\mathrm{CaSO}_{4}$ from 0.002 to $0.01 \mathrm{M}$ increased the overall calcium carbonate solubility product more than an order of magnitude (Chong \& Sheikholeslami 2001).

\section{Iron sulfides}

Kennedy et al. (1999) found solid-phase sulfide minerals near the core of the plume of a gasolinecontaminated aquifer. They concluded that an accurate estimation of hydrocarbon bioremediation demanded that solid Fe and $\mathrm{S}$ minerals be evaluated along with the aqueous-phase concentration of sulfide. We first summarize the aqueous sulfide system and then crit- ically review the formation and dissolution of several iron-sulfide solids.

\section{The aqueous sulfide species}

The aqueous sulfide system has three main species that are related through two acid-base reactions:

$$
\begin{gathered}
\mathrm{H}_{2} \mathrm{~S}_{(\mathrm{aq})} \leftrightarrows \mathrm{HS}^{-}+\mathrm{H}^{-} \quad \mathrm{pK}_{\mathrm{a} 1}=6.98 \pm 0.02 \text { at } 25^{\circ} \mathrm{C} \\
\mathrm{HS}^{-} \leftrightarrows \mathrm{S}^{2-}+\mathrm{H}^{+} \quad \mathrm{pK}_{\mathrm{a} 2}=17.3 \pm 0.3 \text { at } 25^{\circ} \mathrm{C}
\end{gathered}
$$

The acidity constant for the first deprotonation reaction $\left(\mathrm{pK}_{\mathrm{a} 1}\right)$ is well established at the value shown above (Davison 1991). The literature reports a range of values for the second deprotonation, because the formation of polysulfides at high $\mathrm{pH}$ makes it difficult to determine the acidity of a specific species. The $\mathrm{pK}_{\mathrm{a} 2}$ value given above, reported by Davison (1991), is based on a careful review of all available literature. According to Boulegue \& Michard (1979), the presence of polysulfides can be neglected in freshwater systems, even though it clouds the determination of $\mathrm{pK}_{\mathrm{a} 2}$.

\section{Iron monosulfide $(\mathrm{FeS})$ versus pyrite $\left(\mathrm{FeS}_{2}\right)$}

Iron(II) and sulfide can form many different minerals, each with its unique stoichiometry and solubility. Table 2 shows the most important iron sulfides occurring in aqueous environments. Davison (1991) reviewed the ion-activity products from various data sets to find indications about the governing minerals. When the ion-activity products for iron sulfides were measured in freshwaters in which solid-phase iron(II) sulfide definitely was present, the values were within the range of 2.6-3.2 (at $25^{\circ} \mathrm{C}$ ), indicating that amorphous FeS was the controlling phase. The values found with seawater $\left(2.7-4.2\right.$ at $\left.25^{\circ} \mathrm{C}\right)$ imply that mackinawite or greigite may be the controlling phase.

These findings show that we must focus on amorphous iron monosulfide (FeS) and its formation. Rickard (1995) reported that the formation of FeS is very fast with no nucleation effects and the product being exclusively amorphous. The 'half-live' for sulfide is below $0.05 \mathrm{~s}$ (time where $50 \%$ of the sulfide reacted at a $\mathrm{Fe}^{2+}$ concentration between $10^{-3}$ and $10^{-4} \mathrm{M}$ ). With respect to biological processes or other relevant precipitation reactions, which have a 'half-life' of reactants in the range of minutes or days, FeS forma- 
Table 2. Solubility product for various iron-sulfide solids according to the reviews of Davison (1991) and Davison et al. (1999). All values are $-\log \left(K_{\text {sp }}\right)$ given for $25^{\circ} \mathrm{C}$ and the reactions below the table entries

\begin{tabular}{|c|c|c|c|c|}
\hline \multicolumn{2}{|c|}{ Mineral name and formula } & \multirow{2}{*}{$\begin{array}{l}\text { Reaction } \\
(5)\end{array}$} & \multirow{2}{*}{$\frac{p K_{\mathrm{sp}}}{3.6 \pm 0.2}$} & \multirow{2}{*}{$\begin{array}{l}\text { Reference } \\
\text { Davison (1991) }\end{array}$} \\
\hline Mackinawite & $\mathrm{Fe}_{1.06} \mathrm{~S}$ & & & \\
\hline \multirow[t]{2}{*}{ Amorphous } & $\mathrm{FeS}$ & (5) & $2.95 \pm 0.1$ & Davison (1991) \\
\hline & & (5) & $3.00 \pm 0.1$ & Davison et al. (1999) \\
\hline Pyrrhotite* & $\mathrm{Fe}_{7} \mathrm{~S}_{8}$ & (5) & $5.1 \pm 0.1$ & Davison (1991) \\
\hline Greigite & $\mathrm{Fe}_{3} \mathrm{~S}_{4}$ & (6) & $4.4 \pm 0.1$ & Davison (1991) \\
\hline Pyrite & $\mathrm{FeS}_{2}$ & $(7$ & $16.4 \pm 1.2$ & Davison (1991) \\
\hline \multicolumn{2}{|c|}{${ }^{*}$ Enthalpy $\Delta H_{r}^{298}$ for Pyrrhotite $\left(\mathrm{kJ} \mathrm{mol}^{-1}\right)$} & $(5)$ & 32.5 & Davison (1991) \\
\hline \multicolumn{5}{|l|}{ Reactions } \\
\hline \multirow{3}{*}{\multicolumn{2}{|c|}{$\begin{array}{l}\mathrm{FeS}+\mathrm{H}^{+} \leftrightarrows \mathrm{Fe}^{2+}+\mathrm{HS}^{-} \\
\frac{1}{3} \mathrm{Fe}_{3} \mathrm{~S}_{4}+\mathrm{H}^{+} \leftrightarrows \mathrm{Fe}^{2+}+\mathrm{HS}^{-}+\frac{1}{3} \mathrm{~S}^{0} \\
\mathrm{FeS}_{2}+\mathrm{H}^{+} \leftrightarrows \mathrm{Fe}^{2+}+\mathrm{HS}^{-}+\mathrm{S}^{0}\end{array}$}} & \multicolumn{3}{|l|}{ (5) } \\
\hline & & \multicolumn{3}{|l|}{ (6) } \\
\hline & & (7) & & \\
\hline
\end{tabular}

tion in freshwater can be treated as a fast equilibrium reaction, and no kinetics have to be considered.

Pyrite, $\mathrm{FeS}_{2}$, is thermodynamically and kinetically by far the most stable occurring iron sulfide in marine and freshwater environments. It reacts only with oxidizing acids and some other oxidants like iron(III) and halogens (Huertadiaz \& Morse 1990; Luther 1990, 1991). Jakobsen \& Postma (1999) found that the sulfide solid ultimately produced in a sulfate-reducing aquifer was framboidal pyrite. Reports of other disulfide formations are rare. Pyrrhotite $\left(\mathrm{Fe}_{7} \mathrm{~S}_{8}\right)$ seems not to be formed in aqueous environments, although thermodynamic reasoning shows a large stability region. Marcasite $\left(\mathrm{Fe}_{1.06} \mathrm{~S}\right)$ has significance below $\mathrm{pH} 5$, but will change to the thermodynamically more stable pyrite through a solid-state transformation. Nothing is known about the mechanisms and the kinetics of this reaction (Rickard et al. 1995).

$\mathrm{FeS}_{2}$ does not nucleate from iron monosulfide in saturated solutions; however, pyrite can grow from FeS in a saturated solution (Rickard et al. 1995). This finding, coupled with the fact that natural freshwater easily shows an ion-activity product that is significantly super-saturated for $\mathrm{FeS}_{2}$ (Davison 1991) and FeS precipitation has extremely rapid kinetics (Rickard 1995), makes it very likely that pyrite is mainly formed through iron-monosulfide as an intermediate.

\section{Pyrite formation pathways and kinetics}

Pyrite possibly can be formed from FeS through three pathways. In each pathway, the $\mathrm{S}$ in $\mathrm{FeS}$ is oxidized by one electron, and the ultimate sink of the electron distinguishes the pathways.

1. FeS, $\mathrm{H}_{2} \mathrm{~S}$, and $\mathrm{H}_{2}$ pathway

$$
\mathrm{FeS}+\mathrm{H}_{2} \mathrm{~S} \leftrightarrows \mathrm{FeS}_{2}+\mathrm{H}_{2}
$$

This reaction, observed by Taylor et al. (1979) and Drobner et al. (1990), has a free energy change of $-34.14 \mathrm{~kJ} \mathrm{~mol}^{-1}$ and an equilibrium constant of $10^{6.1}$ (defined by the ratio of the partial pressure of hydrogen gas divided by the $\mathrm{H}_{2} \mathrm{~S}$ activity, and at $298 \mathrm{~K}$ ). Two publications (Rickard 1997; Rickard \& Luther 1997) indicated the following kinetics based on measurements and theoretical considerations:

$$
\rho=k \cdot[\mathrm{FeS}] \cdot\left[\mathrm{H}_{2} \mathrm{~S}\right]_{\mathrm{aq}}
$$

where $\rho$ is the formation rate of pyrite $\left[\mathrm{M} \mathrm{s}^{-1}\right]$, $[\mathrm{FeS}]$ is the concentration of ironsulfide $[\mathrm{M}]$, $\left[\mathrm{H}_{2} \mathrm{~S}\right]_{\mathrm{aq}}$ is the aqueous $\mathrm{H}_{2} \mathrm{~S}$ concentration [M] and $k$ is the second-order rate constant, estimated to be $1.03 \times 10^{-4} \mathrm{M}^{-1} \mathrm{~s}^{-1}$ at $25^{\circ} \mathrm{C}$ with an apparent (Arrhenius) activation energy of $35 \mathrm{~kJ} \mathrm{~mol}^{-1}$. The $\mathrm{FeS} / \mathrm{H}_{2} \mathrm{~S} / \mathrm{H}_{2}$ pathway is by far the most rapid of the pyrite-forming reactions. In strictly anaerobic environments, it probably is the most important pyrite-forming pathway.

Very noteworthy is the abiotic generation of $\mathrm{H}_{2}$ as part of the $\mathrm{FeS} / \mathrm{H}_{2} \mathrm{~S} / \mathrm{H}_{2}$ pathway, because $\mathrm{H}_{2}$ is the sink for the two electrons removed from $\mathrm{S}$ in $\mathrm{FeS}$ and $\mathrm{H}_{2} \mathrm{~S}$. Hydrogen generation through this process is an electron-donor substrate for all respiring microorganisms. For instance, $\mathrm{H}_{2}$ produced 
abiotically from this pathway could fuel methane production and give false evidence of methanogenesis related to BTEX bioremediation. Furthermore, abiotically produced hydrogen potentially could confound using hydrogen as a indicator of the governing electron acceptor in natural attenuation of a groundwater (Jakobsen \& Postma 1999).

2. Oxidative conversion of FeS by elemental sulfur

$$
\mathrm{FeS}+\mathrm{S}^{0} \leftrightarrows \mathrm{FeS}_{2}
$$

The conversion of solid iron sulfide to pyrite in the presence of elemental sulfur $\left(\mathrm{S}^{0}\right)$ was described in several investigations and reviewed by Rickard et al. (1995) and Furukawa \& Barnes (1995). Here, elemental sulfur accepts the electron removed from $\mathrm{S}$ in FeS. Little is known about the mechanism and kinetics, and Furukawa \& Barnes (1995) conclude that the conversion of iron monosulfide in parallel with the loss of iron(II) (described in the next section) is much more likely than the reduction and incorporation of elemental sulfur (Wang \& Morse 1996).

3. Polysulfide pathways

Theoretical considerations of molecular orbitals suggest that the following reactions, which involve polysulfide $\left(\mathrm{S}_{x}^{2-}\right.$, where $x$ indicate multiple $\mathrm{S}$ atoms), could be a mechanism for pyrite formation (Luther 1991; Rickard 1975; Schoonen \& Barnes 1991):

$$
\begin{aligned}
\mathrm{FeS}+\mathrm{S}_{x}^{2-} \leftrightarrows\left[\mathrm{FeS}_{x+1}\right]^{2-} \leftrightarrows \mathrm{FeS}_{2}+\mathrm{S}_{(x-1)}^{2-} \\
\begin{aligned}
\mathrm{Fe}(\mathrm{SH})_{2}+\mathrm{S}_{x}^{2-} & \leftrightarrows\left[\mathrm{Fe}(\mathrm{SH})_{2} \mathrm{~S}_{x}\right]^{2-} \\
& \leftrightarrows \mathrm{FeS}_{2}+\mathrm{S}_{(x+1)}^{2-}+2 \mathrm{H}^{+}
\end{aligned}
\end{aligned}
$$

Similar to the reaction with elemental sulfur, the electron released from the $\mathrm{S}$ in $\mathrm{FeS}$ goes to reduce polysulfide $\mathrm{S}$ from an oxidation state of 0 to -1 . Luther (1991) also noted the possibility of polysulfides directly attacking FeS forming on the surface of $\mathrm{FeOOH}$. Under typical groundwater conditions, polysulfides are not important (Boulegue \& Michard 1979), and, therefore, these two reactions probably do not have any significance.

Although $\mathrm{FeS}_{2}$ could be formed from $\mathrm{FeS}$ by three pathways, the evidence supports that only the $\mathrm{FeS} / \mathrm{H}_{2} \mathrm{~S} / \mathrm{H}_{2}$ pathway is significant for groundwater conditions.

\section{Pyrite $\left(\mathrm{FeS}_{2}\right)$ oxidation}

Pyrite oxidation has been studied extensively in the laboratory with a focus on inorganic reaction kinetics (Moses et al. 1987; Nicholson et al. 1988, 1990; Moses \& Herman 1991; Williamson \& Rimstidt 1992, 1994) and bacterial catalysis (Nordstrom \& Southam 1997; Bond et al. 2000; Edwards et al. 2000). The oxidation of pyrite can be described by the following reactions:

$$
\begin{aligned}
& \mathrm{FeS}_{2}+14 \mathrm{Fe}^{3+}+8 \mathrm{H}_{2} \mathrm{O} \rightarrow 15 \mathrm{Fe}^{2+}+2 \mathrm{SO}_{4}^{2-} \\
&+16 \mathrm{H}^{+} \\
& 15 \mathrm{Fe}^{2+}+3.75 \mathrm{O}_{2}+15 \mathrm{H}^{+} \rightarrow 15 \mathrm{Fe}^{3+}+7.5 \mathrm{H}_{2} \mathrm{O} \\
& \mathrm{Fe}^{3+}+1.5 \mathrm{H}_{2} \mathrm{O} \rightarrow 0.5 \mathrm{Fe}_{2} \mathrm{O}_{3}+3 \mathrm{H}^{+}
\end{aligned}
$$

All three reactions lead to the overall net reaction:

$$
\begin{aligned}
\mathrm{FeS}_{2}+3.75 \mathrm{O}_{2}+2 \mathrm{H}_{2} \mathrm{O} \rightarrow & 0.5 \mathrm{Fe}_{2} \mathrm{O}_{3}+2 \mathrm{SO}_{4}^{2-} \\
& +4 \mathrm{H}^{+}
\end{aligned}
$$

Reaction (16) shows that the oxidation of pyrite consumes oxygen and generated sulfate, which can confound footprints for BTEX biodegradation aerobically or by sulfate-reduction.

$\mathrm{Xu}$ et al. (2000) present a kinetic model for pyrite oxidation and give a good overview of the rates published in literature. If oxygen is available, then reaction (14) usually is biologically catalyzed, so that reaction (13) determines the overall pyrite oxidation rate. Typical oxidation rates range from $9.6 \times 10^{-9}$ to $1.9 \times 10^{-8} \mathrm{~mol} \mathrm{~m}^{-2} \mathrm{~s}^{-1}$ (moles of pyrite oxidation per square meter reactive surface area per second).

\section{Reductive dissolution of iron(III) with oxidation of sulfide}

Dissolved sulfide can be oxidized in the presence of solid iron(III) minerals such as goethite $(\alpha-\mathrm{FeOOH})$ or hematite $\left(\alpha-\mathrm{Fe}_{2} \mathrm{O}_{3}\right)$ (Rickard 1974; Pyzik \& Sommer 1981; Canfield 1989; Canfield et al. 1992). The reaction rate depends strongly on the $\mathrm{pH}$, with a maximum between 6.5 and 7.0, depending on the mineral. The products of this reaction are iron(II) and elemental sulfur $\left(\mathrm{S}_{8}^{0}\right)$, sulfate $\left(\mathrm{SO}_{4}^{2-}\right)$, or thiosulfate $\left(\mathrm{S}_{2} \mathrm{O}_{3}^{2-}\right)$. The possible net reactions with hematite $\left(\mathrm{Fe}_{2} \mathrm{O}_{3}\right)$ as the iron mineral are summarized in Table 3 . In all cases, $\mathrm{Fe}(\mathrm{II})$ is released to solution by an abiotic process, not microbially catalyzed BTEX oxidation coupled to 
Table 3. Net reactions for the reductive dissolution of iron oxides leading to different sulfurous products

$4 \mathrm{Fe}_{2} \mathrm{O}_{3}+2 \mathrm{H}_{2} \mathrm{~S}+14 \mathrm{H}^{+} \leftrightarrows \mathrm{S}_{2} \mathrm{O}_{3}^{2-}+9 \mathrm{H}_{2} \mathrm{O}+8 \mathrm{Fe}_{\mathrm{aq}}^{2+}$
$4 \mathrm{Fe}_{2} \mathrm{O}_{3}+\mathrm{H}_{2} \mathrm{~S}+14 \mathrm{H}^{+} \leftrightarrows \mathrm{SO}_{4}^{2-}+8 \mathrm{H}_{2} \mathrm{O}+8 \mathrm{Fe}_{\mathrm{aq}}^{2+}$
$8 \mathrm{Fe}_{2} \mathrm{O}_{3}+8 \mathrm{H}_{2} \mathrm{~S}+32 \mathrm{H}^{+} \leftrightarrows \mathrm{S}_{8}^{0}+24 \mathrm{H}_{2} \mathrm{O}+16 \mathrm{Fe}_{\mathrm{aq}}^{2+}$
$(x-1) \mathrm{Fe}_{2} \mathrm{O}_{3}+\mathrm{Fe}_{2} \mathrm{O}_{3}+x \mathrm{H}_{2} \mathrm{~S}+(x-6) \mathrm{H}^{+} \leftrightarrows \mathrm{S}_{x}^{2-}+3(x-1) \mathrm{H}_{2} \mathrm{O}+2(x-1) \mathrm{Fe}_{\mathrm{aq}}^{2+}$

Fe(III) reduction. Furthermore, sulfide, a key footprint of sulfate reduction, is consumed. These abiotic reactions can confound interpretation of footprints of BTEX biodegradation via sulfate and iron reductions.

\section{Kinetics and mechanisms}

Dos Santos Afonso \& Stumm (1992) investigated $\mathrm{H}_{2} \mathrm{~S}$ oxidation on hematite and interpreted the rate law by assuming a surface-controlled mechanism having the following sequence of reactions:

(a) $\mathrm{S}$ surface complex formation

$$
\equiv \mathrm{Fe}^{\mathrm{III}} \mathrm{OH}+\mathrm{HS}^{-} \leftrightarrows \equiv \mathrm{Fe}^{\mathrm{III}} \mathrm{S}^{-}+\mathrm{H}_{2} \mathrm{O}
$$

(b) Electron transfer

$$
\equiv \mathrm{Fe}^{\mathrm{III}} \mathrm{S}^{-} \leftrightarrows \equiv \mathrm{Fe}^{\mathrm{II}} \mathrm{S}
$$

(c) Hydrolysis and release of the S-product

$$
\equiv \mathrm{Fe}^{\mathrm{III}} \mathrm{S}^{-}+\mathrm{H}_{2} \mathrm{O} \leftrightarrows \equiv \mathrm{Fe}^{\mathrm{II}} \mathrm{OH}_{2}^{+}+\mathrm{S}^{--}
$$

(d) Regeneration of the surface site and release of the $\mathrm{Fe}(\mathrm{II})$ product

$$
\equiv \mathrm{Fe}^{\mathrm{II}} \mathrm{OH}_{2}^{+} \rightarrow \mathrm{Fe}^{\mathrm{III}} \mathrm{OH}+\mathrm{Fe}_{\mathrm{aq}}^{2+}
$$

A similar sequence of reaction can be written for the surface complex $\equiv$ FeSH.

$\mathrm{S}^{-}$- formed in reaction (23) reacts with iron oxide to form sulfate $\left(\mathrm{SO}_{4}^{2-}\right)$, thiosulfate $\left(\mathrm{S}_{2} \mathrm{O}_{3}^{2-}, \mathrm{O}_{4}^{2-}\right)$, or elemental sulfur $\left(\mathrm{S}^{0}\right)$ in subsequent fast steps. Elemental sulfur seems to be the dominant product of the sulfide oxidation with $\mathrm{Fe}(\mathrm{OH})_{3}$ and $\mathrm{FeOOH}$ as iron minerals (Yao \& Millero 1996b; Peiffer et al. 1992; Pyzik \& Sommer 1981; Rickard 1974), whereas Dos Santos Afonso \& Stumm (1992), who used hematite, reported sulfate as the major product. The net reactions are given in reactions (17) to (20) (in Table 3), depending on the product formed.

Dos Santos Afonso \& Stumm (1992) estimated the equilibrium constants of the surface complexes involved in the reductive dissolution of iron oxides (Table 4). If these complexation reactions are fast enough to go to equilibrium, the rate of sulfide oxidation is proportional to the concentration of the surface species $\left\{\equiv \mathrm{FeS}^{-}\right\}$and $\{\equiv \mathrm{FeSH}\}$ (in $\left[\mathrm{mol} \mathrm{m}^{-2}\right]$ ):

$$
\rho\left[\text { mole } \mathrm{m}^{-2} \mathrm{~h}^{-1}\right]=k_{e 1} \cdot\left[\equiv \mathrm{FeS}^{-}\right]+k_{e 2} \cdot[\equiv \mathrm{FeSH}]
$$

From experimental results, the rate constants were estimated with $k_{e 1}=30 \mathrm{~h}^{-1}$ and $k_{e 2}=400 \mathrm{~h}^{-1}$ (Dos Santos Afonso \& Stumm 1992), where the concentrations of the surface species are expressed in mol $\mathrm{m}^{-2}$. The surface-speciation model was successfully applied by Peiffer et al. (1992) and Yao \& Millero $(1996 \mathrm{a}, \mathrm{b})$ to explain the $\mathrm{pH}$ dependency of

\begin{tabular}{|c|c|c|}
\hline Species & Equation & $\log K$ \\
\hline$\equiv \mathrm{FeOH}_{2}^{+}$ & $\equiv \mathrm{FeOH}_{2}^{+} \leftrightarrows \equiv \mathrm{FeOH}+\mathrm{H}^{+}$ & $-7.25(26)$ \\
\hline$\equiv \mathrm{FeO}^{-}$ & $\equiv \mathrm{FeOH}_{2}^{+} \leftrightarrows \equiv \mathrm{FeO}^{-}+\mathrm{H}^{+}$ & $-9.75(27)$ \\
\hline$\equiv \mathrm{FeSH}$ & $\equiv \mathrm{FeOH}+\mathrm{H}_{2} \mathrm{~S}_{(\mathrm{aq})} \leftrightarrows \equiv \mathrm{FeSH}+\mathrm{H}_{2} \mathrm{O}$ & $3.80 \quad(28)$ \\
\hline$\equiv \mathrm{FeS}^{-}$ & $\equiv \mathrm{FeOH}+\mathrm{H}_{2} \mathrm{~S}_{(\mathrm{aq})} \leftrightarrows \equiv \mathrm{FeS}^{-}+\mathrm{H}_{3} \mathrm{O}^{+}$ & -1.72 \\
\hline$\equiv \mathrm{FeS}^{-}$ & $\equiv \mathrm{FeSH} \leftrightarrows \equiv \mathrm{FeS}^{-}+\mathrm{H}^{+}$ & $-5.52(30)$ \\
\hline
\end{tabular}
the observed reaction rate.

Table 4. Equilibrium constants $\left(25^{\circ} \mathrm{C}, 1 \mathrm{~atm}, \mathrm{I}=0\right)$ for the surface complexation involved in the reductive dissolution of iron oxides (from Dos Santos Afonso \& Stumm 1992)

\section{Influences on the sulfide oxidation rate}

Yao \& Millero (1995) give an excellent overview of the influences of various ions and organic ligands on the rate of sulfide oxidation. Generally, strong adsorption to the mineral surface slows the reaction rate.

- Type of iron mineral: The rate of sulfide oxidation varies with different forms of iron(III) oxides and decreases in the following order: $\mathrm{Fe}(\mathrm{OH})_{3}>$ $\gamma \mathrm{FeOOH}>\beta \mathrm{FeOOH}>\alpha \mathrm{FeOOH}>\alpha \mathrm{Fe}_{2} \mathrm{O}_{3}$. This is decrease of the rate is proportional to the 
increase of the free energy of the redox half reactions of $\mathrm{Fe}(\mathrm{OH})_{3}, \mathrm{FeOOH}$, and $\mathrm{Fe}_{2} \mathrm{O}_{3}$ (Dos Santos Afonso \& Stumm 1992; Yao \& Millero 1995).

- Anions: Phosphate and sulfate decrease the reaction rate significantly. In seawater, sulfate is the main reason for the slow turnover rate. $\mathrm{Si}(\mathrm{OH})_{4}$ and $\mathrm{HCO}_{3}^{-}$only have a very small negative influences on the reaction kinetics.

- Cations: No or only a slight influence could be found for $\mathrm{NH}_{4}^{+}, \mathrm{NH}_{4}^{+}, \mathrm{Mn}^{2+}, \mathrm{Fe}^{2+}, \mathrm{Ca}^{2+}$, and $\mathrm{Mg}^{2+}$.

- Organic ligands: The investigated organic ligands were humic acid $(10 \mathrm{mg} / \mathrm{l})$, fulvic acid $(10 \mathrm{mg} / \mathrm{l})$, EDTA $(500 \mu \mathrm{M})$, TRIS $(25 \mathrm{mM})$, and oxalate $(500 \mu \mathrm{M})$. All of them had a relatively strong negative influence ( $50 \%$ reduction) on the sulfidereduction rate.

\section{Conclusions}

The footprints of BTEX biodegradation can be confounded by the stepwise nature of the biodegradation reactions and by several abiotic chemical reactions that also produce or consume the footprints. In this work, we present the scientific foundation for understanding why the following five features need to be included in a model used to evaluate natural attenuation of BTEX and how to represent them properly:

(1) Fermentation and methanogenesis must be treated as separate processes, because the two steps produce or consume key footprints $\left(\mathrm{H}_{2}\right.$, inorganic carbon, and acetic acid) in distinct and often opposite ways.

(2) Precipitation and dissolution of calcite consume or produce two key footprints (inorganic carbon and alkalinity) and affect the $\mathrm{pH}$.

(3) Precipitation of amorphous iron monosulfide (FeS) occurs rapidly and consumes two key footprints, $\mathrm{Fe}(\mathrm{II})$ and $\mathrm{H}_{2} \mathrm{~S}$.

(4) Conversion of FeS into the thermodynamically stable pyrite $\left(\mathrm{FeS}_{2}\right)$ brings about loss of $\mathrm{H}_{2} \mathrm{~S}$, but is an abiotic source of $\mathrm{H}_{2}$.

(5) Reductive dissolution of solid iron(III) by oxidation of sulfide consumes oxygen while producing sulfate.

Our companion manuscript (Maurer and Rittmann, this volume) develops and applies a mathematical model that includes these reactions with the traditional biodegradation reactions for BTEX.

\section{References}

Acton DW \& Barker JF (1992) In-situ biodegradation potential of aromatic-hydrocarbons in anaerobic groundwaters. J. Contam. Hydrol. 9: 325-352

Bariteau A \& Thiry M (2001) Analysis and simulation of the geochemical transfers within an aquifer: the Beauce ground-water and the alteration of the Fontainebleau Sands. Bulletin De La Societe Geologique De France 172(3): 367-381

Bielefeldt AR \& Stensel HD (1999a) Evaluation of biodegradation kinetic testing methods and longterm variability in biokinetics for BTEX metabolism. Water Res. 33: 733-740

Bielefeldt AR \& Stensel HD (1999b) Modeling competitive inhibition effects during biodegradation of BTEX mixtures. Water Res. 33: 707-714

Bond PL, Druschel GK \& Banfield JF (2000) Comparison of acid mine drainage microbial communities in physically and geochemically distinct ecosystems. Appl. Environ. Microbiol. 66: 4962-4971.

Boulegue J \& Michard G (1979) Sulphur speciations and redox processes in reducing environments. In: Jenne EA (Ed) Chemical Modelling in Aqueous Systems (pp 25-50). American Chemical Society, Washington, D.C

Busenberg E \& Plummer LN (1986) A comparative study of the dissolution and crystal growth kinetics of calcite and aragonite. In: Mumpton FA (Ed) Studies on Diagenesis, Vol. 1578 (pp 139168). USGS Bulletin, Denver, CO

Canfield DE (1989) Reactive iron in marine-sediments. Geochimica et Cosmochimica Acta 53: 619-632

Canfield DE, Raiswell R \& Bottrell S (1992) The reactivity of sedimentary iron minerals toward sulfide. Am. J. Sci. 292: 659-683

Chapelle FH, Haack SK, Adriaens P, Henry MA \& Bradley PM (1996) Comparison of $\mathrm{E}(\mathrm{H})$ and $\mathrm{H}-2$ measurements for delineating redox processes in a contaminated aquifer. Environ. Sci. Technol. 30: 3565-3569

Chapelle FH, McMahon PB, Dubrovsky NM, Fujii RF, Oaksford ET \& Vroblesky DA (1995) Deducing the distribution of terminal electron-accepting processes in hydrologically diverse groundwater systems. Water Resour. Res. 31: 359-371

Chaudhuri BK \& Wiesmann U (1996) Kinetic study of the anaerobic degradation of toluene by a mixed culture. Acta Biotechnologica 16: $31-41$

Chong TH \& Sheikholeslami R (2001) Thermodynamics and kinetics for mixed calcium carbonate and calcium sulfate precipitation. Chem. Eng. Sci. 56: 5391-5400

Chou L, Garrels RM \& Wollast R (1989) Comparative study of the kinetics and mechanisms of dissolution of carbonate minerals. In: Schott J \& Lasaga AC (Eds) Kinetic Geochemistry, vol. 78 (pp 269-282)

Clement TP (1997) Rt3d - a modular computer code for simulating reactive multi-species transport in 3-dimensional groundwater systems. The U.S. Department of Energy, PNNL-SA-11720, Contract DE-AC06-76RLO 1830

Coates JD, Ellis DJ, Gaw CV \& Lovley DR (1999) Geothrix fermentans Gen. Nov., Sp Nov., a novel Fe(Iii)-reducing bacterium from a hydrocarbon-contaminated aquifer. Int. J. System. Bacteriol. 49: 1615-1622

Cozzarelli IM, Baedecker MJ, Eganhouse RP \& Goerlitz DF (1994) The geochemical evolution of low-molecular-weight organicacids derived from the degradation of petroleum contaminants in groundwater. Geochimica et Cosmochimica Acta 58: 863-877

Davison W (1991) The solubility of iron sulfides in synthetic and natural-waters at ambient-temperature. Aqua. Sci. 53: 309-329 
Davison W, Phillips N \& Tabner BJ (1999) Soluble iron sulfide species in natural waters: Reappraisal of their stoichiometry and stability constants. Aqua. Sci. 61(1): 23-43

Dawe RA \& Zhang YP (1997) Kinetics of calcium carbonate scaling using observations from glass micromodels. J. Petrol. Sci. Eng. 18: $179-187$

Dolfing J (1988) Acetogenesis. In: Zehnder AJB (Ed) Biology of Anaerobic Microorganisms (pp 417-468). John Wiley, New York

Dos Santos Afonso MD \& Stumm W (1992) Reductive dissolution of iron(Iii) (hydr)oxides by hydrogen-sulfide. Langmuir 8: 16711675

Drobner E, Huber H, Wachtershauser G, Rose D \& Stetter KO (1990) Pyrite formation linked with hydrogen evolution under anaerobic conditions. Nature 346: 742-744

Edwards KJ, Bond PL, Druschel GK, McGuire MM, Hamers RJ \& Banfield JF (2000) Geochemical and biological aspects of sulfide mineral dissolution: lessons from Iron Mountain, California. Chem. Geol. 169: 383-397

Edwards EA \& Grbicgalic D (1994) Anaerobic degradation of toluene and $\mathrm{O}$-xylene by a methanogenic consortium. Appl. Environ. Microbiol. 60: 313-322

Eisenlohr L, Meteva K, Gabrovsek F \& Dreybrodt W (1999) The inhibiting action of intrinsic impurities in natural calcium carbonate minerals to their dissolution kinetics in aqueous $\mathrm{H}_{2} \mathrm{O}-\mathrm{Co}_{2}$ solutions. Geochimica et Cosmochimica Acta 63: 989-1001

Furukawa Y \& Barnes HL (1995) Reactions forming pyrite from precipitated amorphous ferrous sulfide. In: Geochemical Transformations of Sedimentary Sulfur, Vol. 612 (pp 194-205). ACS Symposium Series

Gersberg RM, Dawsey WJ \& Bradley MD (1991) Biodegradation of monoaromatic hydrocarbons in groundwater under denitrifying conditions. Bull. Environ. Contam. Toxicol. 47: 230-237

Grbicgalic D (1991) Anaerobic transformation of aromatic hydrocarbon pollutants under fermentative methanogenic conditions. Periodicum Biologorum 93: 533-546

Grbicgalic D \& Vogel TM (1987) Transformation of toluene and benzene by mixed methanogenic cultures. Appl. Environ. Microbiol. 53: 254-260

Gutjahr A, Dabringhaus H \& Lacmann R (1996) Studies of the growth and dissolution kinetics of the $\mathrm{CaCo}_{3}$ polymorphs calcite and aragonite. 1. Growth and dissolution rates in water. J. Cryst. Growth 158: 296-309

Holliger C \& Zehnder AJB (1996) Anaerobic biodegradation of hydrocarbons. Curr. Opin. Biotechnol. 7: 326-330

Huertadiaz MA \& Morse JW (1990) A quantitative method for determination of trace-metal concentrations in sedimentary pyrite. Marine Chem. 29: 119-144

Hunkeler D, Jorger D, Haberli K, Hohener P \& Zeyer J (1998) Petroleum hydrocarbon mineralization in anaerobic laboratory aquifer columns. J. Contam. Hydrol. 32: 41-61

Hutchins SR, Miller DE \& Thomas A (1998) Combined laboratory/field study on the use of nitrate for in situ bioremediation of a fuel-contaminated aquifer. Environ. Sci. Technol. 32: 1832-1840

Jakobsen R, Albrechtsen HJ, Rasmussen M, Bay H, Bjerg PL \& Christensen TH (1998) H-2 concentrations in a landfill leachate plume (Grindsted, Denmark): in situ energetics of terminal electron acceptor processes. Environ. Sci. Technol. 32: 2142-2148

Jakobsen R \& Postma D (1999) Redox zoning, rates of sulfate reduction and interactions with Fe-reduction and methanogenesis in a shallow sandy aquifer, Romo, Denmark. Geochimica et Cosmochimica Acta 63: 137-151

Katsifaras A \& Spanos N (1999) Effect of inorganic phosphate ions on the spontaneous precipitation of vaterite and on the transformation of vaterite to calcite. J. Cryst. Growth 204: 183-190
Kennedy LG, Everett JW, Dewers T, Pickins W \& Edwards D (1999) Application of mineral iron and sulfide analysis to evaluate natural attenuation at fuel contaminated site. J. Environ. Engin.-Asce 125: 47-56

Kostka JE \& Nealson KH (1995) Dissolution and reduction of magnetite by bacteria. Environ. Sci. Technol. 29: 2535-2540

Landmeyer JE, Vroblesky DA \& Chapelle FH (1996) Stable carbon isotope evidence of biodegradation zonation in a shallow jet-fuel contaminated aquifer. Environ. Sci. Technol. 30: 1120-1128

Lovley DR, Chapelle FH \& Woodward JC (1994) Use of dissolved $\mathrm{H}(2)$ concentrations to determine distribution of microbially catalyzed redox reactions in anoxic groundwater. Environ. Sci. Technol. 28: 1205-1210

Lovley DR, Coates JD, Woodward JC \& Phillips EJP (1995) Benzene oxidation coupled to sulfate reduction. Appl. Environ. Microbiol. 61: 953-958

Luther GW (1991) Pyrite synthesis via polysulfide compounds. Geochimica et Cosmochimica Acta 55: 2839-2849

Luther GWI (1990) The frontier-molecular-orbital theory approach in geochemical processes. In: Stumm W (Ed) Aquatic Chemical Kinetics (pp 173-198), John Wiley, New York

Major DW, Mayfield CI and Barker JF (1988) Biotransformation of benzene by denitrification in aquifer sand. Ground Water 26: $8-14$

Malmstead MJ, Brockman FJ, Valocchi AJ \& Rittmann BE (1995) Modeling biofilm biodegradation requiring cosubstrates - the quinoline example. Water Sci. Technol. 31: 71-84

Meckenstock RU, Morasch B, Warthmann R, Schink B, Annweiler E, Michaelis W \& Richnow HH (1999) C-13/C-12 isotope fractionation of aromatic hydrocarbons during microbial degradation. Environ. Microbiol. 1: 409-414

Millero F, Huang F, Zhu XR, Liu XW \& Zhang JZ (2001) Adsorption and desorption of phosphate on calcite and aragonite in seawater. Aqua. Geochem. 7: 33-56

Morgan P, Lewis ST \& Watkinson RJ (1993) Biodegradation of benzene, toluene, ethylbenzene and xylenes in gas-condensatecontaminated groundwater. Environ. Pollut. 82: 181-190

Mormile MR \& Suflita JM (1996) The toxicity of selected gasoline components to glucose methanogenesis by aquifer microorganisms. Anaerobe 2: 299-303

Morse JW \& Berner RA (1979) Chemistry of calcium carbonate in deep ocean. In: Jenne EA (Ed) Chemical Modelling in Aqueous Systems, Vol. 93 (pp 499-535). Am. Chem. Coc., Symp. Ser.

Morse JW and Mackenzie FT (1990) Geochemistry of Sedimentary Carbonates. Elsevier, Amsterdam.

Moses CO and Herman JS (1991) Pyrite oxidation at circumneutral $\mathrm{Ph}$. Geochimica et Cosmochimica Acta 55: 471-482

Moses CO, Nordstrom DK, Herman JS \& Mills AL (1987) Aqueous pyrite oxidation by dissolved-oxygen and by ferric iron. Geochimica et Cosmochimica Acta 51: 1561-1571

Nancollas GH \& Reddy MM (1971) The crystallization of calcium carbonate. Ii. calcite growth mechanism. J. Coll. Inter. Sci. 37: 824-829

Neal C, Jarvie HP, Williams RJ, Neal M, Wickham H \& Hill L (2002) Phosphorus-calcium carbonate saturation relationships in a lowland chalk river impacted by sewage inputs and phosphorus remediation: an assessment of phosphorus self-cleansing mechanisms in natural waters. Sci. Total Environ. 282: 295-310

Nicholson RV, Gillham RW \& Reardon EJ (1990) Pyrite oxidation in carbonate-buffered solution. 2. Rate control by oxide coatings. Geochimica et Cosmochimica Acta 54: 395-402

Nicholson RV, Gillham RW \& Reardon EJ (1988) Pyrite oxidation in carbonate-buffered solution. 1. Experimental kinetics. Geochimica et Cosmochimica Acta 52: 1077-1085 
Nilsson O \& Sternbeck J (1999) A mechanistic model for calcite crystal growth using surface speciation. Geochimica et Cosmochimica Acta 63: 215-223

Nordstrom DK \& Southam G (1997) Geomicrobiology of sulfide mineral oxidation. In: Geomicrobiology: Interactions between Microbes and Minerals, Vol. 35 (pp 361-390). Mineralogical Society America, Washington

NRC (National Research Council (1993) In situ Bioremediation: When Does It Work?, National Academy Press, Washington, D.C

NRC (National-Research-Council) (2000) Natural Attenuation for Groundwater Remediation. National Academy Press, Washington, D.C

Ohara M \& Reid RC (1973) Modeling Crystal Growth Rates from Solution. Prentice-Hall, Englewood Cliffs, NJ, 272 pp

Palmer AN (1991) The origin and morphology of limestone caves. Geol. Sci. Am. Bull. 103: 1-21

Parsiegla KI \& Katz JL (1999) Calcite growth inhibition by copper(Ii) I. Effect of supersaturation. J. Cryst. Growth 200: 213226

Patel GB, Agnew BJ \& Dicaire CJ (1991) Inhibition of pure cultures of methanogens by benzene-ring compounds. Appl. Environ. Microbiol. 57: 2969-2974

Peiffer S, Dos Santos Afonso MD, Wehrli B \& Gächter R (1992) Kinetics and mechanism of the reaction of $\mathrm{H} 2 \mathrm{~s}$ with lepidocrocite. Environ. Sci. Technol. 26, 2408-2413

Plummer LN \& Busenberg E (1982) The solution of calcite, aragonite and vaterite in $\mathrm{CO}_{2}-\mathrm{H}_{2} \mathrm{O}$ solution between 0 and $90{ }^{\circ} \mathrm{C}$ and an evaluation of the aqueous model for the system $\mathrm{CaCO}_{3}-$ $\mathrm{CO}_{2}-\mathrm{H}_{2} \mathrm{O}$. Geochim. Cosmochim. Acta. 46: 1011-1040

Plummer LN, Busenberg E \& Riggs AC (2000) In situ growth of calcite at Devils Hole, Nevada: comparison of field and laboratory rates to a 500,000 year record of near-equilibrium calcite growth. Aqua. Geochem. 6: 257-274

Plummer LN, Wigley T \& Parkhurst DL (1978) The kinetics of calcite dissolution in $\mathrm{CO}_{2}$-water systems at $5^{\circ}$ to $60{ }^{\circ} \mathrm{C}$ and 0.0 to $1.0 \mathrm{~atm} \mathrm{CO}_{2}$. Am. J. Sci. 278: 179-216

Pokrovsky OS \& Schott J (2001) Kinetics and mechanism of dolomite dissolution in neutral to alkaline solutions revisited. Am. J. Sci. 301: 597-626

Pokrovsky OS \& Schott J (2002) Surface chemistry and dissolution kinetics of divalent metal carbonates. Environ. Sci. Technol. 36: 426-432

Pope GA, Sepehrnoori K, Sharma MM, McKinney DC, Speitel GEJ \& Jackson RE (1999) Three-dimensional Napl fate and transport model (Utchem). EPA, United States Environmental Protection Agency, EPA/600/R-99/011, February 1999, Cincinnati, OH 45268. EPA/600/R-99/011

Postma D \& Jakobsen R (1996) Redox zonation: equilibrium constraints on the $\mathrm{Fe}$ (Iii)/So4- Reduction Interface. Geochimica et Cosmochimica Acta 60: 3169-3175

Pyzik AJ \& Sommer SE (1981) Sedimentary iron monosulfides: kinetics and mechanism of formation. Geochimica et Cosmochimica Acta 45: 687-698

Rafai HS, Newell CJ, Gonzales JR, Dendrou S, Kennedy L \& Wilson JT (1998) Bioplume Iii - Natural Attenuation Decision Support System - User's Manual Version 1.0. EPA, United States Environmental Protection Agency, Washington, DC

Reinhard M, Shang S, Kitanidis PK, Orwin E, Hopkins GD \& Lebron CA (1997) In situ BTEX biotransformation under enhanced nitrate- and sulfate-reducing conditions. Environ. Sci. Technol. 31: 28-36

Revesz K, Coplen TB, Baedecker MJ, Glynn PD \& Hult M (1995) Methane production and consumption monitored by stable $\mathrm{H}$ and
C isotope ratios at a crude oil spill site, Bemidji, Minnesota. Appl. Geochem. 10: 505-516

Rickard D (1974) Kinetics and mechanism of the sulfidation of goethite. Am. J. Sci. 274: 636-652

Rickard D (1975) Kinetics and mechanism of pyrite formation at low temperatures. Am. J. Sci. 275: 941-952

Rickard D (1995) Kinetics of Fes precipitation. 1. Competing reaction-mechanisms. Geochimica et Cosmochimica Acta 59: 4367-4379

Rickard D (1997) Kinetics of pyrite formation by the $\mathrm{H}_{2}$ s oxidation of iron (Ii) monosulfide in aqueous solutions between 25 and $125^{\circ} \mathrm{C}$ : The rate equation. Geochimica et Cosmochimica Acta 61: $115-134$

Rickard D \& Luther GW (1997) Kinetics of pyrite formation by the $\mathrm{H}_{2} \mathrm{~s}$ oxidation of iron(Ii) monosulfide in aqueous solutions between 25 and $125^{\circ} \mathrm{C}$ : The mechanism. Geochimica et Cosmochimica Acta 61: 135-147

Rickard D, Schoonen MAA \& Luther GW (1995) Chemistry of iron sulfides in sedimentary environments. In: Vairavamurthy MA \& Schoonen MAA (Eds) Geochemical Transformations of Sedimentary Sulfur, Vol. 612 (pp 168-193), American Chemical Society, Washington, DC

Rittmann BE, Banaszak JE \& Reed DT (2002) Reduction of $\mathrm{Np}(\mathrm{V})$ and precipitation of $\mathrm{Np}(\mathrm{IV})$ by an anaerobic microbial consortium. Biodegradation 13(5): 329-342

Rittmann BE, Seagren E, Wrenn BA, Valocchi AJ, Ray C \& Raskin L (1994) In situ bioremediation, 2nd edn, Noyes Publications, Park Ridge, NJ

Salanitro JP, Wisniewski HL, Byers DL, Neaville CC \& Schroder RA (1997) Use of aerobic and anaerobic microcosms to assess BTEX biodegradation in aquifers. Ground Water Monitor. Remed. 17: 210-221

Schäfer D, Schäfer W \& Kinzelbach W (1998a) Simulation of reactive processes related to biodegradation in aquifers. 1. Structure of the three-dimensional reactive transport model. J. Contam. Hydrol. 31: 167-186

Schäfer D, Schäfer W \& Kinzelbach W (1998b) Simulation of reactive processes related to biodegradation in aquifers. 2. Model application to a column study on organic carbon degradation. J. Contam. Hydrol. 31: 187-209

Schoonen MAA \& Barnes HL (1991) Reactions forming pyrite and marcasite from solution. 2. Via Fes precursors below $100{ }^{\circ} \mathrm{C}$. Geochimica et Cosmochimica Acta 55: 1505-1514

Sherman LA \& Barak P (2000) Solubility and dissolution kinetics of dolomite in $\mathrm{Ca}-\mathrm{Mg}-\mathrm{HCO}_{3} / \mathrm{CO}_{3}$ solutions at $25{ }^{\circ} \mathrm{C}$ and 0.1 MPa carbon dioxide. Soil Sci. Soc. Am. J. 64: 1959-1968

Spanos N \& Koutsoukos PG (1998) Kinetics of precipitation of calcium carbonate in alkaline $\mathrm{Ph}$ at constant supersaturation. Spontaneous and seeded growth. J. Phys. Chem. B 102: 66796684

Sternbeck J (1997) Kinetics of rhodochrosite crystal growth at $25{ }^{\circ} \mathrm{C}$ : The role of surface speciation. Geochimica et Cosmochimica Acta 61(4): 785-793

Stumm W \& Morgan JJ (1996) Aquatic Chemistry. John Wiley, New York

Svensson U \& Dreybrodt W (1992) Dissolution kinetics of natural calcite minerals in $\mathrm{CO}_{2}$-water systems approaching calcite equilibrium. Chem. Geol. 100: 129-145

Taylor P, Rummery TE \& Owen DG (1979) Reactions of iron monosulfide solids with aqueous hydrogen sulfide up to $160^{\circ} \mathrm{C}$. J. Inorganic Nucl. Chem. 41: 1683-1687

Van Cappellen P, Charlet L, Stumm W \& Wersin P (1993) A surface complexation model of the carbonate mineral-aqueous 
solution interface. Geochimica et Cosmochimica Acta 57(15): 3505-3518

Vogel TM \& Grbicgalic D (1986) Incorporation of oxygen from water into toluene and benzene during anaerobic fermentative transformation. Appl. Environ. Microbiol. 52: 200-202

Vroblesky DA \& Chapelle FH (1994) Temporal and spatial changes of terminal electron-accepting processes in a petroleum hydrocarbon-contaminated aquifer and the significance for contaminant biodegradation. Water Resour. Res. 30: 1561-1570

Wang QW \& Morse JW (1996) Pyrite formation under conditions approximating those in anoxic sediments. 1. Pathway and morphology. Marine Chem. 52: 99-121

Wiedemeier T, Wilson JT, Kampbell DH, Miller RN \& Hansen JE (1995) Technical protocol for implementing intrinsic remediation with long-term monitoring for natural attenuation of fuel contamination dissolved in groundwater. Air Force Center for Environmental Excellence Technology Transfer Division, Brooks Air Force Base, 11/11/95, San Antonio, TX

Williamson MA \& Rimstidt J D (1992) Correlation between structure and thermodynamic properties of aqueous sulfur species. Geochimica et Cosmochimica Acta 56: 3867-3880
Williamson MA \& Rimstidt JD (1994) The kinetics and electrochemical rate-determining step of aqueous pyrite oxidation. Geochimica et Cosmochimica Acta 58: 5443-5454

Wollast R (1990) Rate and mechanism of dissolution of carbonates in the system $\mathrm{CaCO}_{3}-\mathrm{MgCO}_{3}$. In: Stumm W (Ed) Aquatic Chemical Kinetics (pp 431-445). John Wiley, New York

Xu TF, White SP, Pruess K \& Brimhall GH (2000) Modeling of pyrite oxidation in saturated and unsaturated subsurface flow systems. Transport Porous Med. 39(1): 25-56

Yao WS \& Millero FH (1995) Oxidation of hydrogen sulfide by $\mathrm{Mn}(\mathrm{IV})$ and $\mathrm{Fe}(\mathrm{III})$ (hydr)oxides in seawater. In: Geochemical Transformations of Sedimentary Sulfur, Vol. 612 (pp 260-279). ACS Symposium Series

Yao WS \& Millero FJ (1996a) Adsorption of phosphate on manganese dioxide in seawater. Environ. Sci. Technol. 30: 536-541

Yao WS \& Millero FJ (1996b) Oxidation of hydrogen sulfide by hydrous Fe(Iii) oxides in seawater. Marine Chem. 52: 1-16 
